\title{
The Emergence and Trajectories of Struggles for an 'African University': The Case of Unfinished Business of African Epistemic Decolonisation
}

\author{
SABELO J. NDLOVU-GATSHENI \\ Professor and Director of Scholarship, Change Management Unit, \\ University of South Africa
}

The decolonial departure point of this article is that every human being is born into a valid and legitimate knowledge system. This means that African people had their own valid and legitimate indigenous systems of education prior to colonisation. However, the dawn and unfolding of Eurocentric modernity through colonialism and imperialism unleashed a particularly racial ethnocentric attitude that led European colonialists to question the very humanity of African people. This questioning and sometimes outright denial of African people's humanity inevitably enabled not only genocides but epistemicides, linguicides and cultural imperialism. The long-term consequence was that Western education became propagated as the only valid and legitimate form of socialisation of humanity across space and time. Needless to say, indigenous African systems of education were displaced as the idea of the modern university took root in Africa. This article flashes back to precolonial African/Nilotic/Arab/Muslim intellectual traditions in its historical reflection on the idea of the university in Africa. It posits a 'triple heritage' of higher education, which embraces Western imperial/ colonial modernity and anti-colonial nationalist liberatory developmentalism in its engagement with the contested idea of the university in Africa. The article critically examines the long and ongoing African struggles for an 'African university'. It locates the struggles for an African university within the broader context of African liberation struggles, the search for modern African identity, autonomous African development and self-definition. Four core challenges constitutive of the struggle for an African university are highlighted: the imperative of securing Africa as a legitimate epistemic base from which Africans view and understand the world; the task of 'moving the centre' through shifting the geography and biography of knowledge in a context where what appears as 'global knowledge' still cascades from a hegemonic centre (Europe and North America); the necessity of 'rethinking thinking itself' as part of launching epistemic disobedience to Eurocentric thinking; and the painstaking decolonial process of 'learning to unlearn in order to relearn', which calls on African intellectuals and academics to openly acknowledge their factory faults and 'miseducation', cascading from their very production by problematic 'Western-styled' universities, including those located in Africa, so as to embark on decolonial self-re-education.

\section{Keywords}

university in Africa, African university, decolonisation, indigenous systems of education,

Western education 


\section{Introduction}

The 'university in Africa' has three genealogies if not 'triple heritages.' The first is the precolonial African/Bantu/Nilotic/Arabic/Muslim genealogy. The precolonial genealogy speaks to the intellectual tradition of the Nile Valley Egyptian-NubianEthiopian civilisation, the Afro-Arabic/Muslim intellectual tradition as well as the precolonial Mali-Songhai-Ghana Timbuktu intellectual tradition, which, taken together, produced the earliest universities on the African soil. ${ }^{2}$ The University of Qarawiyyin in Fes in Morocco, founded in AD 859; the University of Al-Azhar in Cairo in Egypt, founded in AD 972; and Sankoré University in Timbuktu in Mali, traceable to the twelfth century, constitute some of the oldest universities in the world. ${ }^{3}$ These institutions, just like their modern counterparts, were preoccupied with understanding the world, the nature of the human, dynamics of society, and the promotion of agriculture, health, literature and philosophy. ${ }^{4}$

The foundational base for the precolonial genealogy of the university has been a combination of the African indigenous education system and the Islamic system of education. The 'primary' teacher in the African indigenous education system was the mother. ${ }^{5}$ But the teaching of the mother was not limited to 'primary' education only. What is emphasised here is the role of what Oyeronke Oyewumi termed 'maternal ideology', which compelled 'obedience from everyone who gestated in a womb. ${ }^{6}$ Grandmothers were also important teachers within the African indigenous education system. They actively participated in primary education and their most common pedagogical mode was folktales delivered in the evening mainly to children. ${ }^{7}$ What also manifested and reinforced the 'maternal ideology' within African indigenous education was the primacy of what is known as the 'mother tongue' as the language of instruction in precolonial Africa. ${ }^{8}$ Oyewumi's most recent work, entitled What Gender Is Motherhood?, highlights the 'supremacy of motherhood' in Yoruba precolonial epistemology. 9 She coined and introduced the concept of 'matripotency' to highlight the centrality of motherhood in Ifa - 'the most important endogenous

1 The concept of 'triple heritage' is borrowed from Ali A. Mazrui, The Africans: A Triple Heritage (London: BBC Publications, 1986).

2 N'Dri T. Assié-Lumumba, Higher Education in Africa: Crises, Reforms and Transformation (Dakar: Codesria, 2006). See also Jacob E.A Ajayi, K.H. Lameck and G. Goma, The African Experience with Higher Education (Accra: Association of African Universities, 1996).

3 Asavia Wandira, The African University in Development (Johannesburg: Ravan Press, 1977), 38.

4 Ajayi et al., The African Experience with Higher Education. See also Y.G.M. Lulat, 'Confronting the Burden of the Past: The Historical Antecedents of the Present Predicament of African Universities' in J.C. Smart, ed., Higher Education: Handbook of Theory and Research: Volume XVIII (London: Kluwer Academic Publishers, 2003), 595-667.

5 The term 'primary' is used here in two senses. The first is importance and the second is a reference to the closeness of the mother to the children so as to inculcate the earliest form of education. See Jacob F. Ajayi, 'The Education Process and Historiography in Contemporary Africa: Background Paper' in Unesco, The Education Process and Historiography in Africa (Paris: Unesco, 1985), $11-20$.

6 Oyeronke Oyewumi citing Nkiru U. Nzegwu, Family Matters: Feminist Concepts in African Philosophy of Culture (New York: State University of New York Press, 2006), 53.

7 Sabelo J. Ndlovu-Gatsheni, The Ndebele Nation: Reflections on Historiography, Hegemony and Memory (Amsterdam and Pretoria: Rozenberg Publishers and Unisa Press, 2009).

8 This point is delivered strongly by Ngugi wa Thiong'o - see In the Name of the Mother: Reflections on Writers and Empire (Nairobi: East African Educational Publishers, 2013).

9 Oyeronke Oyewumi, What Gender Is Motherhood? Changing Yoruba Ideas of Power, Procreation, and Identity in the Age of Modernity (London: Palgrave Macmillan, 2016). 
system of knowledge. ${ }^{10}$ Oyewumi provides this definition of the Yoruba endogenous system of knowledge:

Ifa is a system of knowledge that was transmitted orally originally. Structured into the institution are sets of procedures that facilitate the retrieval of information on all aspects of Yoruba life past, present, and future. The knowledge is made accessible through a system of divination, a process that generates stories, myths, and narratives that profess to be God send, and which make assertions about anything and everything in Yoruba life. $^{11}$

Ifa is a clear example of one constitutive element of African indigenous knowledge systems. To some extent the identity of who propagated African indigenous education depended on the nature of the African precolonial society, that is, whether it was a patriarchal society where men constituted the household heads or a matriarchal one where women led in society. ${ }^{12}$ But even in matriarchal societies men were not excluded from teaching. While in the African indigenous education system, education was not formally organised hierarchically into 'primary', 'secondary' and 'higher' education, one can argue (without necessarily falling into what Mahmood Mamdani termed writing African history 'by analogy') that the 'primary' institution of learning was the extended family. ${ }^{13}$ Beyond the mothers as primary teachers in the African indigenous education system, there were many other specialised teachers in precolonial Africa, including priests, diviners, kings, chiefs, poets, griots, rainmakers and merchants who constituted what the distinguished historian Toyin Falola termed 'traditional intellectuals. ${ }^{14}$ Due to the knowledge they embodied, generated and disseminated, these 'traditional intellectuals' exercised considerable power and authority. Besides the family as the 'primary' school, there were other important schools in precolonial Africa, such as the famous initiation schools and age-set institutions where knowledges of masculinity, femininity, entry into adulthood, collective identity, working together and patriotism were inculcated. ${ }^{15}$ Individualism was not promoted in African indigenous education. Harmony between humans and nature was emphasised.

However, it was only when the African indigenous education system intersected with the Islamic/Arabic system of education that it embraced the alphabet and a writing system in addition to its primary oral transmission. The oldest known writing system in Africa is hieroglyphics, found in Egypt - an African/Arabic site of knowledge

10 Ibid., 2.

11 Ibid., 12.

12 For details on patriarchal and matriarchal societies, see the work of Ifi Amadiume, Male Daughters, Female Husbands: Gender and Sex in an African Society (London: Zed Books, 1987).

13 Mahmood Mamdani, Citizen and Subject: Contemporary Africa and the Legacy of Late Colonialism (Princeton, NJ: Princeton University Press, 1996).

14 Toyin Falola, Nationalism and African Intellectuals (Rochester, NY: University of Rochester Press, 2004 ), 3.

15 Ndlovu-Gatsheni, The Ndebele Nation. 
generation including arithmetic, geometry and algebra. ${ }^{16}$ Highlighting the intersection of Islamic and African indigenous education systems is not intended to downplay the Arab colonisation of Africa, but rather to highlight how the two systems of education influenced each other in terms of cultures, values and philosophies. ${ }^{17}$ The intersections of the African indigenous education system and the Islamic education system are reflected in the cross-cutting recognition of ancestors, 'the cult of saints, some aspects of the mysticism of Sufi orders and maraboutism' in Islamic thought and education..$^{18}$ The intersections also reflect in Semitic languages such as Amharic. It was this intersectionality of languages, knowledges and religions that provoked Ali A. Mazrui to coin the concept of 'Afrabia' and to push for the 'abolition' of the Red Sea as a boundary separating Africa and Arabia. ${ }^{19}$ It is this perspective of the intersection of cultures that gave birth to the concept of 'triple heritage' that is traceable to Edward Wilmot Blyden, ${ }^{20}$ Kwame Nkrumah ${ }^{21}$ and Mazrui. ${ }^{22}$ The concept of 'triple heritage' acknowledges that three civilisations shaped contemporary Africa: Africa's own rich cultures/traditions, Islamic cultures/traditions and Western cultures/traditions.

Thus, the precolonial Mali-Songhai-Ghana Timbuktu and the precolonial African/Nilotic/Arabic/Muslim intellectual traditions which produced the first African universities are a collective pride of Africans, African Muslims and ArabMuslim Africans. What is disappointing though is the weak link between the precolonial African universities and the modern 'university in Africa. Even those that have survived, like the Al-Azhar University in Cairo and the University of Qarawiyyin in Fes, seem not to have managed to escape westernisation. Factors which help to explain the discontinuity rather than continuity include 'the breakup of the Sudanic Empires and the coming of the slave trade', which resulted in Africa suffering 'a period of relative intellectual isolation and stagnation. ${ }^{23}$ The scramble for Africa, the partition of Africa and the conquest of Africa 'did not assist the intellectual recovery of the continent. ${ }^{24}$ However, the continuing existence of the Al-Azhar University in Cairo enables us to talk of the 'Alexandria model' of the university.

Below I turn to the second and third genealogies of the idea of the university in Africa through critically reflecting on the Western imperial/colonial tradition as well as the anti-colonial African nationalist liberatory developmental heritage. However, the former has had the most enduring impact and even the anti-colonial African nationalist liberatory developmental genealogy could not fully decentre it. ${ }^{25}$ 16 See Cheikh A. Diop, Precolonial Black Africa: A Comparative Study of the Political and Social Systems of Europe and Black Africa,
from Antiquity to the Formation of Modern States, translated by Harold J. Salemson (Trenton, NJ: Africa World Press, 1987). See also George G. Joseph, The Crest of the Peacock: Non-European Roots of Mathematics (Princeton and Oxford: Princeton University Press, 2011).

17 Ajayi, 'The Educational Process and Historiography in Contemporary Africa'.

18 Ibid., 12-13.

19 Ali A. Mazrui, 'Towards Abolishing the Red Sea and Re-Africanizing the Arabian Peninsula' in Jeffrey C. Stone, ed., Africa and the Sea: Proceedings of a Colloquium at the University of Aberdeen, March 1984 (Aberdeen: Aberdeen University, 1984), 98-104.

20 Edward W. Blyden, Christianity, Islam and the Negro Race (London: Edinburgh University Press, 1888 [1967]).

21 Kwame Nkrumah, Consciencism: Philosophy and Ideology for De-Colonization and Development with Particular Reference to the African Revolution (New York: Monthly Review Press, 1964 [1970]).

22 Ali A. Mazrui, The Africans: A Triple Heritage (London: BBC Publications, 1996).

23 Wandira, The African University in Development, 38.

24 Ibid.

25 Apollos O. Nwauwa, Imperialism, Academe and Nationalism: Britain and University Education for Africans 1860-1960 (London: Frank Cass, 1996). 


\section{The genealogies of the modern university in Africa}

The modern university in Africa was both fought for by Africans and a colonial imposition. Early African educated elites like Blyden and James Africanus Beale Horton of Sierra Leone, and J.E. Casely Hayford of Ghana, agitated and fought for the establishment of universities in Africa from as early as $1868 .{ }^{26}$ While these early African educated elites fought for a very particular type of university - the 'African university' (rooted in African cultural and intellectual soil and climate) - the reluctant colonial regimes imposed the 'university in Africa' (transplanted from Europe). The contestation over the model of the university is as old as the initial agitation for the 'African university'. For example, Horton, who in his will gave his own house in Freetown in Sierra Leone to become the nucleus of a university, saw no problem in universities coming to Africa as raw transplants from Europe. He was in favour of 'undiluted Western education. ${ }^{27}$

One can argue that Horton represented a particular constituency of African people who had undergone deep westernisation processes to the extent that they became fully converted to the idea of the superiority of Western education and its values for the rest of humanity. The attitudes and psyches of these Africans revealed the ambivalence born out of their encounters with Western civilisation and the direct impact of Western education on African consciousness. Horton's contemporaries Blyden and Hayford represented another constituency of Western-educated elite that had a radically different take on the nature and character of the higher education they wanted for Africa. Blyden and Hayford exhibited the earliest ideas of a decolonised higher education. According to Eric Ashby, Blyden advocated for an African university that was free from the grip of the despotic Europeanizing influences which had warped and crushed the Negro mind. ${ }^{28}$

Blyden became the leading advocate, if not the pioneer, of the philosophy of 'African personality', which he did not want Western education to destroy. Rather, he wanted it to be nurtured as part of the restoration of African cultural self-respect. The philosophy of 'African personality' was predicated on five key issues: the separate and unique destiny of black people from Europeans; the development of a distinctive African mentality; religion's place of pride in African thought and life; the inherent socialist/communal nature of Africa society; and the strong idea of 'Africa for Africans. ${ }^{29}$ Blyden was opposed to modern Western civilisation as he saw it as a carrier of 'race poison', and harked back to the Greek and Latin civilisations as classics that could nourish Africa intellectually without racism. ${ }^{30}$ Blyden is also the earliest advocate to promote African languages, African songs and African oral traditions as part of higher education. His decolonial ideas were echoed by Reverend

28 Ibid., 12-13. See also Edward Wilmot Blyden, The Aims and Methods of a Liberal Education for Africans: Inaugural Address Delivered by Edward Wilmot Blyden, LLD., President of Liberia College, January 5, 1881 (Cambridge, MA: Harvard University Press, 1882).

29 M. Yu Frankel, 'Edward Blyden and the Concept of African Personality', African Affairs, 73(292) (1974), $277-289$.

30 Ashby, African Universities and Western Tradition, 13. 
James Johnson of Sierra Leone, who wanted a higher education institution that would 'Leave undisturbed our particularities. ${ }^{31}$

Hayford was another early African decolonial thinker who advocated for a decolonised higher education for Africa. His ideas about an indigenous university were captured in his book Ethiopia Unbound. ${ }^{32}$ Hayford, a pioneer African nationalist and advocate of Ethiopianism, was very critical of an African university that was a mere replica of European institutions and that mimicked and reproduced foreign influences. He went further to propose the use of African indigenous languages in teaching and learning. Like Blyden, Hayford was a proponent of an African university that 'would preserve in the students a sense of African Nationality. ${ }^{33}$ If these struggles are taken seriously, they indicate that decolonisation struggles/decoloniality is traceable to as far back as the time of colonial encounters themselves. Decolonisation/decoloniality is one of the most resilient languages of liberation ranged against colonialism/coloniality. It has today re-emerged in a far more radical form in Latin America, where concepts such as coloniality and decoloniality have been coined and where the 'decolonial turn' has been emphasised and is traceable to the Haitian Revolution. The decolonial struggles in the Americas, Asia and Africa which delivered the new flags and anthems are today being carried over to the realm of epistemic freedom. ${ }^{34}$

What happened to these early struggles and demands for an African university is analogous to what happened to the person who cried for a fish and was given a snake instead. In the first place, the colonial regimes argued for a sound African secondary education as an essential prerequisite and foundation for African university education. Second, the early educational institutions established in Africa, such as Fourah Bay College in Sierra Leone (1876), emerged as 'colleges' of overseas universities. ${ }^{35}$ Third, the colonial regimes continued to turn a blind eye to the expansion of higher education for Africans, leaving the missionaries to concentrate on primary and secondary sectors. As argued by Mazrui, mission education inaugurated the first form of African intellectual dependency and acculturation/'cultural schizophrenia' through separating young Africans from their parents and enclosing them in mission boarding schools. ${ }^{36}$ The church and the mission school performed the colonial purpose of the 'desocialization of African education. ${ }^{37}$ The introduction of colonial languages such as English and French completed the desocialisation process. Even more profoundly, Mazrui posited that by the time the European missionaries came to Africa to introduce Christian education and theology, Europe and North America were undergoing secularisation and religion was on the retreat since the time of

Wandira, The African University in Development, 40.

J.E. Casely Hayford, Ethiopia Unbound: Studies in Race Emancipation (London: C.M. Phillips, 1911).

J.E. Casely Hayford, Memorandum of the Case of the National Congress of British West Africa for a Memorial Based Upon the Resolution to be Presented to His Majesty the King Emperor in Council through the Right Honourable the Secretary of State for the Colonies (London, 1911).

34 Sabelo J. Ndlovu-Gatsheni, Coloniality of Power in Postcolonial Africa: Myths of Decolonization (Dakar: Codesria, 2013) and Empire, Global Coloniality and African Subjectivity (New York and Oxford: Berghahn Books, 2013).

35 Fourah Bay College was part of the University of Durham in the United Kingdom and the curriculum came from there. Students sat for examinations set in Britain.

36 Ali A. Mazrui, Political Values and the Educated Class in Africa (Berkeley, MA, and Los Angeles, CA: University of California Press, 1978), 27.

Ibid., 29. 
Enlightenment. ${ }^{38}$ Thus, it is in the unfolding of mission education in Africa that the origins of the crisis of relevance lie of the (mis)education of the African.

\section{The 'Jones colleges' and 'Asquith colleges'}

The response to the African struggles and demands for higher education was a series of colonial commissions in the 1920s, 1930s and 1940s. In 1920/1921, the Phelps Stokes Fund in the USA sent a commission led by Jesse Jones to enquire into education in Africa. The commission confirmed the hunger for higher education in West, South and Equatorial Africa. The Jones commission's findings culminated in the White Paper of 1925, which emphasised that education should be adapted to the African context. ${ }^{39}$ The core message of the White Paper was that 'Education should be adapted to the mentality, aptitudes, occupations and traditions of the various peoples, conserving as far as possible all sound and healthy elements in the fabric of their social life. 40

But it was only in 1933 that James Currie, who was part of an Advisory Committee on Education in the Colonies under the terms of the White Paper of 1925, produced a brief report making 'an eloquent and urgent plea for the founding of universities in tropical Africa. ${ }^{41}$ The combined results of these initiatives were a few colleges ('Jones Colleges') that emerged between 1922 and 1934: Makerere College in Uganda (1922); Gordon Memorial College and the Kitchener School of Medicine in Khartoum in Sudan (1924); the Princess of Wales School and College in Achimota in Ghana (1927); and Higher College in Yaka in Nigeria (1934). ${ }^{42}$

According to Asavia Wandira, the Jones Colleges faced two 'conceptual problems'. The first he described as the 'problem of apex', which spoke to the necessity of synchronising the need for a university with the level reached by the secondary education system. The second problem spoke to comparable standards - should the Jones Colleges be allowed to depart from recognised international standards and establish an identity of their own ${ }^{23}$ These two problems were reflected in the recommendations of the British Advisory Committee on Education in the Colonies of 1933, but the 1937 De La Warr Commission nonetheless recommended developing Makerere College in Uganda into the University College for East Africa:

We are aware of the present very flimsy foundations of primary and secondary education upon which such institutions will need to be based, and realize the possible risks of too rapid advance and of a top heavy structure. Nevertheless, we are convinced that the material needs of the country and

\footnotetext{
38 Ibid.

39 Wandira, The African University in Development.

40 Ashby, African Universities and Western Tradition, 16.

41 Ibid., 17.

42 Wandira, The African University in Development.

43 Ibid.
} 
the intellectual needs of its people require that such risks as there may, should be taken. ${ }^{44}$

Another factor that informed the colonial reluctance to establish universities in Africa was monetary in nature: who was going to pay for them? It was not until the adoption of the Colonial Development and Welfare Paper of 1940, which became the basis for the Colonial Development and Welfare Act, that the British government committed itself to funding universities in Africa. However, another Commission on Higher Education in the Colonies was launched in 1943, under the chairmanship of Justice Asquith, and its 1945 report became the basis for developing university colleges after the end of the Second World War.

Ashby argues that 'The Asquith Report was Britain's blueprint for the export of universities to her people overseas. ${ }^{45}$ This is why such 'university colleges' as the Ibadan in Nigeria, Legon in Ghana, Khartoum in Sudan, Mona in the West Indies and Makerere in Uganda became known as 'Asquith Colleges'. As noted by Ashby, the basic assumption of the 'Asquith Doctrine' 'was that a university system appropriate for Europeans brought up in London and Manchester and Hull was also appropriate for Africans brought up in Lagos and Kumasi and Kampala." ${ }^{46}$ The university colleges in Salisbury (University College of Rhodesia/University of Zimbabwe), Nairobi (University of Nairobi) and Dar-es-Salaam (University of Dar-es-Salaam) emerged later but as part of the existing Asquith Colleges' imperial/colonial tradition. These university colleges became sites of the coloniality of knowledge, cultural imperialism and purveyors of Eurocentric knowledge. In francophone Africa, institutions of higher learning such as the University of Dakar unproblematically took the model of the university system in France as well as standards from Paris and Bordeaux. The same is true of the University of Kinshasa, which closely embraced the model and curriculum of the University of Louvain in Brussels, Belgium. ${ }^{47}$

South African universities emerged as part of the imperial/colonial/apartheid tradition. Their earlier emergence than those in the rest of Africa was due to the fact that, from the beginning of the unfolding of colonial modernity, South Africa was imagined as a 'little Europe' at the southern tip of the African continent. ${ }^{48}$ There was a long-standing white presence, since 1652, and over the years a white South Africa emerged through the process of a 'moving frontier' and 'great treks' from the coast, conquering, dispossessing, displacing and occupying what used to be black indigenous people's land. ${ }^{49}$ Because of its European character, South Africa's first university, known as the South African College, was established in 1829 - in 1918 it officially became the University of Cape Town. This was an English university that

4 Ibid., 12

Ashby, African Universities and Western Tradition, 19.

Ibid.

Wandira, The African University in Development.

8 On how South Africa was imagined as a 'little Europe', see Bernard M. Magubane, Race and the Construction of the Dispensable Other (Pretoria: Unisa Press, 2007).

49 Norman Etherington, The Great Treks: The Transformation of Southern Africa 1815-1854 (London: Longman/Pearson Education, 2001). 
catered for and prepared white students for degree examinations of the University of London. Africans were not admitted into the university. It was not until 1916 that the first university for Africans was established, known as the South African Native College of Fort Hare. ${ }^{50}$ Although South Africa had many colleges and universities before 1948 - such as South African College/University of Cape Town (1829); Grey College/the University College of the Orange Free State/University of the Orange Free State (1855); St. Andrews College/Rhodes University College/Rhodes University (1855); Stellenbosch Gymnasium/Stellenbosch College/Victoria College/University of Stellenbosch (1866); Theological School of the Reformed Church/Potchefstroom University College/Potchefstroom University for Christian Higher Education (1869) - they did not admit black people.

To understand the South African situation one has to delve deeper into the broader early white colonial thought and later apartheid thought about Africans. Suffice to say that the London Missionary Society under Superintendent John Philip, and other denominational missionaries, provided African education (known as 'native education') through mission schools. ${ }^{51}$ Native education was a particular form of education which, under the apartheid regime, became known as 'Bantu Education'. This provoked South African anti-colonial leader Isaac Bongani Tabata of the NonEuropean Unity Movement to declare:

The apostles of Apartheid have fathered a new monstrosity, called Bantu Education, by means of which they aim to arrest the development of the African people, who comprise more than nine million, or nearly three-quarters of the total population. It has its counter-part in 'Coloured Education' for the Coloured people of South Africa, comprising, with Indians, about one and a half million. They want to re-create for the subject races a social order belonging to the pre-industrial age. ${ }^{52}$

Tabata described 'Bantu Education' as 'education for barbarism' because it was not meant to be 'intellectual' but was deliberately invented as 'industrial. Through this type of education, African people were being prepared to be providers of desperately needed cheap labour. ${ }^{53}$ For its genesis, one has to go back to Philip's 1828 paper 'Researches in South Africa'. There he laid down the role of the Christian missionary as being to spread British imperial/colonial interests in South Africa and the purpose of 'native education' as being to eradicate 'native indolence' in order for Africans to be useful servants and labourers of the colony. ${ }^{54}$ What was distinctive about South African higher education was that from the beginning it was shot through with a strong racial and ethnic paradigm of difference, producing 'English universities',

\footnotetext{
50 Eli Bitzer, ed., Higher Education in South Africa: A Scholarly Look behind the Scenes (Stellenbosch: SUN MeDIA Stellenbosch, 2009).

51 Nosipho Majeke, The Role of the Missionaries in Conquest (Cape Town: Apdusa, 1986).

52 Isaac Bongani Tabata, Education for Barbarism: Bantu (Apartheid) Education in South Africa (London: Prometheus, 1959$), 15$.

53 Malcolm Ray, Free Fall: Why South African Universities Are in a Race against Time (Johannesburg: Bookstorm, 2016).

54 Ibid., 24.
} 
'Afrikaans universities', 'universities for coloureds and Indians' and 'universities for Natives', which were from 1959 further bifurcated into 'black ethnic universities.5. About this segregated higher education, Tabata concluded that:

This Apartheid university education is not simply a matter of separating the races at the universities. It is an end result, the logical completion of a systematic process not only of robbing Non-Whites of education but turning a whole population back to barbarism. To put it another way: if Bantu Education is the bricks of that immense edifice, the retribalization of a whole people, the Apartheid university is its capping stone. ${ }^{56}$

The time of reckoning for South African higher education institutions came in 2015, with students - most of them born after the dismantlement of juridical apartheid - spearheading the struggle for decolonisation of the universities. What has come to be known as the RhodesMustFall movement (discussed later) must be understood as part of the long trajectory in the struggle for the decolonisation of education, which began with the likes of Blyden and Hayford. What compounded the predicament of South African higher education institutions is the fact that while the rest of the African continent began to decolonise after 1945, South Africa entered the difficult journey of institutionalised apartheid in 1948. This resulted in the invention of 'bantustans' at a time when other parts of Africa were gaining political independence. Bantustans were fake 'independent ethnic republics' invented by the apartheid regime but they were politically unsustainable as they were in fact mere reservoirs of black cheap labour for the white-owned economy.

Apartheid, which endured as a colonial racist monstrosity until 1994, consistently struggled not only to keep the people of South Africa in separate race and ethnic groups, but also to keep institutions of higher learning racially and ethnically separated. This history partly explains why Malcolm Ray depicted South African universities as currently engaged 'in a race against time. ${ }^{57}$ Other universities in Africa underwent 'Africanisation' in the 1960s and 1970s. Because of the long shadow of apartheid, South African universities are currently engulfed by the spirit of both Africanisation and decolonisation. What must not be forgotten though, is that the Africanisation and decolonisation of the universities in the 1960s and 1970s was largely superficial, entailing changing the names of universities, taking over the administration of universities by installing black chancellors and vice-chancellors, increasing the number of black academics and black students as well as including work by African academics in the curriculum. This type of Africanisation and decolonisation did not touch the structural Eurocentric epistemological scaffolding on which the university in

55 Christopher White, From Despair to Hope: The Turfloop Experience (Sovenga: University of the North Press, 1997), 69-76.

56 Tabata, Education for Barbarism, 16-17.

57 Ray, Free Fall: Why South African Universities Are in a Race against Time. 
Africa is built and did not constitute the genuine 'epistemic disobedience' called for by advocates of decoloniality. ${ }^{58}$

What was achieved was inclusion of Africans into a long-existing 'European game' without changing the rules of the game..$^{59}$ This is why the struggle for an African university continues. The 'decolonisation' struggle which is upon us is not simply for inclusion but to change the very rules of the game. Its logic is well captured by Catherine Odora Hoppers and Howard Richards in terms of 'rethinking thinking' itself, involving the radical move of 'casting...light at last onto subjugated peoples, knowledges, histories and ways of living', which fundamentally 'unsettles the toxic pond and transforms passive analysis into a generative force that valorizes and recreates life for those previously museumised. ${ }^{60}$ But let us carefully track the trajectories of the African struggle for an African university since 1960 - the year of African political liberation.

\section{The struggle for an African developmental university}

The dawn of African political independence in the 1960s was accompanied by intensified struggles to transform/Africanise/decolonise the university in Africa into an African university. At its deepest level, this struggle entailed formulating a new philosophy of higher education informed by African histories, cultures, ideas and aspirations as well as a fundamental redefinition of the role of the university. But to achieve this decolonial objective, there was a need to navigate carefully not only the imperatives of 'standards' set in Europe and the African local imperatives of the 'social function' of the university, but also the dangers of looking 'inward' at the expense of the universal aspect of knowledge. Mobutu Sese Seko of Zaire expressed the 'inward'-looking imperative when he said:

We need to emancipate the educational system in the Congo from the Western model by going back to the Authenticity while paying due attention to scientific knowledge. I have always thought it inappropriate for us to train our youth as if they were Westerners. It would be more desirable to have an educational system which shapes the youth according to our requirements. That would make them authentically Congolese. Their ideas, reasoning and actions would be Congolese, and they would see the future in Congolese terms. ${ }^{61}$

Walter D. Mignolo, 'Epistemic Disobedience, Independent Thought and De-Colonial Freedom, Theory, Culture and Society, 26(7-8) (2008), 1-23.

59 In The Wretched of the Earth, translated by Richard Philcox (New York: Grove Press, 1963) Frantz Fanon advised colonised people to leave the 'European game' and embark on something new and better as part of the decolonisation project.

60 Catherine Odora Hoppers and Howard Richards, Rethinking Thinking: Modernity's 'Other' and the Transformation of the University (Pretoria: Unisa Press, 2012), 8.

61 Mobutu quoted in Thandika Mkandawire, 'African Intellectuals and Nationalism' in Thandika Mkandawire, ed., African Intellectuals: Rethinking Politics, Language, Gender and Development (Dakar and London: Codesria and Zed Books, 2005), $22-23$. 
Mobutu Sese Seko was an advocate of what became known as 'Authenticite', which entailed even abandoning the use of European names as part of the national project of Africanisation. In a speech delivered at Léopold Sédar Senghor's seventieth birthday celebrations, Mobutu Sese Seko made a distinction between his own idea of authenticity and Senghor's negritude. He said while negritude was a rebellion against the arrogance of the French colonisers, 'authenticity was a rebellion against one's own dependency and imitativeness. ${ }^{62}$ While this was an unexpected and brilliant intervention from Mobutu Sese Seko, what fundamentally discredited his Africanisation project was his anti-human political behaviour, which turned him into the archetypal notorious 'postcolonial' African dictator. He abused the ideologies of decolonisation and African symbolism to invent himself as an 'absolute modern monarch' who single-handedly captured the state of Zaire and successfully turned it into a personal fiefdom, using the country's expansive resources for his personal benefit. Mobutu Sese Seko is a leading example of what Michael G. Schatzberg described as 'Presidential-Father-Chief' of 'middle Africa. ${ }^{63}$

Other African nationalists like Julius Nyerere of Tanzania, who became the first black chancellor of the University of East Africa (consisting of the University of Makerere in Uganda, the University of Nairobi in Kenya and the University of Dares-Salaam in Tanzania) on 28 June 1963, were attentive to the dilemma facing the processes of Africanising the university in Africa:

There are two possible dangers facing a university in a developing nation: the danger of blindly adoring mythical 'international standards' which may cast a shadow on national development objectives, and the danger of forcing our university to look inwards and isolate itself from the world. ${ }^{64}$

While Nyerere emphasised the dangers of failing to maintain a balance between the national and international character of the university in Africa, Mazrui highlighted three important relationships that the university in Africa has to navigate and negotiate:

A university has to be politically distant from the state; secondly, a university has also to be culturally close to society; and thirdly, a university has to be intellectually linked to wider scholarly and scientific values of the world of learning. ${ }^{65}$

At the same time, while Nyerere was cognisant of the dilemma of indigenisation/Africanisation versus internationalisation, like other African nationalists he was

62 Mobutu Sese Seko cited in Mazrui, Political Values and the Educated Class in Africa, 13-14.

63 Michael G. Schatzberg, Political Legitimacy in Middle Africa: Father, Family, Food (Bloomington, IN: Indiana University Press, 2001), 8.

64 Julius K. Nyerere, Freedom and Unity: Uhuru na Umoja. A Selection from Writings and Speeches 1952-65 (Dar-es-Salaam: Oxford University Press, 1966), 218-219.

65 Ali A. Mazrui, 'Towards Re-Africanizing African Universities: Who Killed Intellectualism in the Post-Colonial Era?' Alternatives: Turkish Journal of International Relations, 2(3\&4) (Fall \& Winter 2003), 141. 
forthright about the role that the African university had to play in an independent African state and continent. He demanded that the university 'takes an active part in the social revolution we are engineering' and that social revolution was predicated on nation-building, economic development and promoting African consciousness. ${ }^{66}$ Nyerere elaborated that:

For twentieth century nationalism is part of a social revolution; an essential part of the development of man as a human being whose freedom depends on his equal membership of the world. Modern nationalism is necessarily humanitarian and international; it is therefore incompatible with racialism. One of the basic tasks of this University is to make this truth an instinctive part of our nationalist expression. ${ }^{67}$

Because colonialism had dispossessed Africans, reduced them to 'subjects' rather than 'citizens' and plunged them into poverty and misery, the immediate task of the new black governments was to deliver economic and social development. ${ }^{68}$ It was within this context that the university in Africa was reimagined and redefined as an engine of development - a 'developmental university'. ${ }^{69}$ The universities were expected to carry the burden of African nationalism, which claimed to express African aspirations. But Thandika Mkandawire argues that:

What African governments wanted was not critical support but subservience and sycophancy. With their ears finely tuned to the voices of foreign experts and deaf to local voices, African states simply didn't care about local debates, except when they threatened state authority. ${ }^{70}$

Indeed, while African nationalists were pushing for the Africanisation of universities and urging African intellectuals to be actively engaged in state-led development projects, they also displayed disdain for African intellectuals by inviting foreigners as close advisers. Mkandawire reveals that Nyerere surrounded himself with foreign 'Fabian socialists' in contrast to Tanzanian intellectuals; Kenneth Kaunda of Zambia's closest intellectual associate was John Hatch, who even became the first director of the Institute for Humanism; and Nkrumah surrounded himself with foreign panAfricanists like George Padmore and William E.B. Dubois. ${ }^{71}$

But while African nationalist leaders like Nkrumah were guilty of surrounding themselves with foreign advisers and ignored local intellectuals, they continued to argue for the Africanisation of the university as well as active participation of the university in state development projects. Thus, when Nkrumah officially opened the

\footnotetext{
66 Nyerere, Freedom and Unity, 219.

67 Ibid., 219-220.

68 Mamdani, Citizen and Subject.

69 Mkandawire, 'African Intellectuals and Nationalism'.

70 Thandika Mkandawire, 'Introduction' in Thandika Mkandawire, ed., African Intellectuals: Rethinking Politics, Language, Gender and Development (Dakar and London: Codesria and Zed Books, 2005), 2.

71 Mkandawire, 'African Intellectuals and Nationalism'.
} 
Akuafo Hall of Residence at the University College of Ghana in 1958, he stated: 'We must in the development of our University bear in mind that once it has been planted in African soil it must take root amidst African traditions and culture. ${ }^{12}$ The demand by founding leaders of independent African states for the universities to embrace the national projects spearheaded by the state set the institutions of higher learning into a new relationship with the state. Notions of academic freedom and university autonomy immediately locked horns with state imperatives, to the extent that by as early as 1963, Nkrumah critiqued a particular notion of academic freedom:

There is, however, sometimes a tendency to use the words 'academic freedom' in another sense and to assert the claim that a university is more or less an institution of learning having no respect or allegiance to the community or to the country in which it exists...This assertion is unsound in principle and objectionable in practice. ${ }^{73}$

Nkrumah became notorious for interfering with the universities' autonomy and academic freedom in Ghana. During this period, there was an emerging nationalist belief that universities occupied an important position and could not be left alone to determine their own priorities without the influence of the state and government. ${ }^{74}$ Nkrumah expressed the mood of the time well when he declared that, as the government of Ghana:

We do not intend to sit idly by and see these institutions which are supported by millions of pounds produced out of the sweat and toil of common people continue to be centres of anti-government activities. We want the university college to cease being an alien institution and to take on the character of a Ghanaian University, loyally serving the interests of the nation and the well-being of our people. If reforms do not come from within, we intend to impose them from outside, and no resort to the cry of academic freedom (for academic freedom does not mean irresponsibility) is going to restrain us from seeing that our university is a healthy university devoted to Ghanaian interest. ${ }^{75}$

What is poignant about these utterances of African nationalist leaders is that even the Africanisation initiatives of the 1960s did not take place within a context of social and political harmony and consensus between those in charge of the state and the African intellectuals, most of whom were foreign trained. It would also seem that the nationalist leaders often used the argument of Africanisation as a strategy

\footnotetext{
Ashby, African Universities and Western Tradition, 61.

Ibid., 78.

T.M. Yesufu, 'Emerging Issues of the 1970s' in T.M. Yesufu, ed., Creating the African University: Emerging Issues in the 1970s (Ibadan: Oxford University Press, 1973), 37-81.

75 Nkrumah cited in Mkandawire, 'African Intellectuals and Nationalism', 22.
} 
to interfere and impose their views on the universities. Some African nationalists, like Nnamdi Azikiwe of Nigeria, pushed for the adoption of the 'American model' (Yankee-style) of the university within a context where there was a preoccupation with 'Nigerianisation' as a major component of the national project. ${ }^{76}$ Azikiwe had studied in America and was enchanted by the American model of the university, to the extent of dedicating efforts to creating one in Nigeria. His efforts resulted in the establishment of the University of Nigeria at Nsukka in Eastern Nigeria as a replica of the American model of the university. ${ }^{77}$ What this indicated was that the agenda of Africanising the university in Africa unfolded within the context of a nationalist ideology of 'one country, one university', as part of increasing access to higher education for an African people who had been deliberately starved of higher education by colonial regimes. A major achievement of African nationalism was opening the gates of learning and education to African people.

Thus, on another level, the 1960s constituted the 'golden age' of the African higher education sector. Not only did the institutions of higher learning multiply, but the Africanisation agenda was embraced by leading scholars such as Cheikh Anta Diop, a nationalist scholar based at the University of Dakar, who dedicated his entire career to producing Africa-centred knowledge and exploding the myths created by imperial colonial historiography. ${ }^{78}$ Diop ranks among the founding fathers of 'Afrocentricity' and African nationalist historiography as he consistently worked to claim the Egyptian civilisation as an African invention. A vibrant and respected African Nationalist School emerged at the University of Ibadan in Nigeria, led by historians such as Kenneth Onwuka Dike, Jacob Ade Ajayi, John Omer-Cooper and many others who contributed immensely to the Africanisation of history as a discipline, as well as to the African nation-building project. ${ }^{79}$ Falola provides the most comprehensive and exhaustive definition of nationalist historiography:

[T] he use of history in the service of the nation - a way of writing that makes history valuable in defining the nation and shaping its future. Nationalist historiography is the representation of elite interests in the nation, as the elite uses its knowledge to define its leadership role. It is a counter-discourse used for attacking European representation of Africa. It is a deliberate attempt to provide credible evidence for the achievements of Africa and the glories of the past in order to indicate possibilities for the future and combat racist views that Africans are incapable of managing themselves... Nationalist historiography is about power: the ability of an intelligentsia to assert itself, to generate knowledge about its own people and

76 Uche Okeke, 'Educational Reconstruction in an Independent Nigeria' (PhD thesis, School of Education, New York University, 1946).

77 Ashby, African Universities and Western Tradition.

78 See Cheikh Anta Diop, The African Origin of Civilization: Myth or Reality (Chicago, IL: Lawrence Hill, 1974), Civilization or Barbarism: An Authentic Anthropology (Chicago, IL: Lawrence Hill, 1981) and Precolonial Black Africa (Chicago, IL: Lawrence Hill, 1987), among many others.

79 Chieka Ifemesia, ed., Issues in African Studies and National Education: Selected Work of Kenneth Onwuka Dike (Awka: K.O. Dike Centre, 1988). 
continent, to show where others are either wrong or right in what they say of its people and continent, to attack views and people who are perceived as hostile or racist, to defend people who are patriotic in their representation of Africa, to justify or explain all aspects of African history and institutions that outsiders condemn, and to create a response to the consequences of European domination of the continent. ${ }^{80}$

In terms of key features, nationalist historiography was 'passionate, combative, and revisionist' as it consistently and persistently dethroned the 'Eurocentric perceptions of Africa' and Africans ${ }^{81}$ It was the historians of the Ibadan, Dakar, Maputo and Dar-es-Salaam nationalist history schools that introduced the oral tradition methodology in their writing of African history; they successfully countered the negatives imparted by imperial/colonial historiography; and they shifted the African historical focus from 'conquest' to 'resistance' as part of their recovery of African agency in history. ${ }^{82}$ The nationalist historians also actively and tirelessly worked to change history curricula and to put at the centre of history courses what they termed 'the African factor. ${ }^{83}$

The Dar-es-Salaam School of History, while nationalist in orientation, also increasingly became a home for Marxist thought and political economy approaches. Walter Rodney's celebrated How Europe Underdeveloped Africa proudly represented the ideological orientation and perspective of the Dar-es-Salaam School in the 1970s. ${ }^{84}$ What the Dar-es-Salaam School brought to the fore was the importance of class analysis to understand the questions of capitalist exploitation, and the dynamics of African indigenous producers. It also revealed the existence of various African social formations and processes of accumulation as well as dispossession. ${ }^{85}$ While the Ibadan School was criticised for overconcentrating on political history, to the extent of creating an impression that only kings and queens (Great Man Theory) made African history; for ignoring questions of class, gender, labour and economy; as well as underestimating the epic impact of colonialism on Africa, the Dar-es-Salaam School's Marxist orientation exposed it to criticism of being stuck in economic determinism. ${ }^{86}$ Mazrui criticised the Dar-es-Salaam School for its Marxist approach, arguing that Marxism was a foreign ideology that was stifling the emergence of genuine African thought. ${ }^{87}$ It would seem that what the nationalist historians succeeded in doing was to Africanise history but they failed to decolonise it. This point becomes even more poignant if one takes into account Jacques Depelchin's view that African

\footnotetext{
80 Falola, Nationalism and African Intellectuals, 224.

81 Ibid.

82 Ibid.

83 Toyin Falola, ed., African Historiography: Essays in Honour of J. F. Ade Ajayi (London: Longman, 1993), 72.

84 Walter Rodney, How Europe Underdeveloped Africa (London: Bogle-L'Ouverture Publications, 1972).

85 Arnold J. Temu and Bonaventure Swai, Historians and Africanist Historiography: A Critique (London: Zed Books, 1981).

86 Christopher Wrigley, 'Historicism in Africa: Slavery and State Formation', African Affairs, 70(279) (January 1971), 113-124. See also Peter Ekeh's criticism of the Ibadan School of History in 'Colonialism and Social Structure' (Inaugural Lecture delivered at the University of Ibadan, 5 June 1980).

Ali A. Mazrui, 'Africa, My Conscience and I', Transition, 46(4) (1974), 61-71.
} 
history has remained colonised in terms of its themes, perspectives, periodisation and problems to be investigated. ${ }^{88}$

The formation of the Association of African Universities (AAU) in Rabat in Morocco in 1967 revealed the continued commitment by African leaders to decolonise and Africanise universities in Africa and make them truly African universities. But unlike the nationalist political leaders, African intellectuals never tired of defending so-called 'international standards' while Africanising and decolonising the university in Africa. The AAU expressed adherence to world academic standards and development of a higher education in the service of Africa, and was in favour of linking the African spirit of the university with the pan-African spirit embodied by the Organisation of African Unity. ${ }^{89}$ At its first general conference held in Kinshasa, Zaire, in September 1969, the AAU's chosen theme - 'The University and Development' was revealing of the envisaged role of the university.

\section{Defining and creating the African university}

A 1972 AAU workshop, themed 'Creating the African University: Emerging Issues in the 1970s', which ran from 10-15 July in Accra, Ghana, demonstrated that the struggle for an African university was continuing even within a context where African economies were beginning to collapse. The workshop's purpose was to formulate a new philosophy of higher education and develop institutions of higher education that were truly African, drawing inspiration from Africa, and intelligently dedicated to her ideas and aspirations. ${ }^{90}$ The workshop delegates concluded that an African university must not be an ivory-tower institution occupied by an elite minority 'indifferent to the prevailing poverty and squalor that surround them'. They elaborated that:

The African university must in the 1970s not only wear a different cloak, but must also be differently motivated. It must be made of a different and distinctive substance from the traditions of Western universities, and must evolve a different attitude and a different approach to its task. The truly African university must be one that draws its inspiration from its environment, not a transplanted tree, but growing from a seed that is planted and nurtured in the African soil. ${ }^{91}$

Importantly, the workshop delegates agreed that tinkering with imported ideas was not enough and that what was needed was a fundamental reconceptualisation of the very idea of the university in Africa. In line with this decolonial thinking, six functions of the African university were delineated (Table 1). Publishers, 2005).

89 T.M. Yesufu, 'Introduction' in T.M. Yesufu, ed., Creating the African University: Emerging Issues in the 1970s (Ibadan: Oxford University Press, 1973), 5

90 Ibid.

91 Yesufu, 'Emerging Issues of the 1970s', 40. 
Table 1

Summary of six functions of an African university in the 1970s

\begin{tabular}{ll} 
Function & EXPLANATION \\
$\begin{array}{l}\text { Pursuit, promotion and dissemination } \\
\text { of knowledge }\end{array}$ & $\begin{array}{l}\text { Practical, immediately useful to the ordinary people } \\
\text { and locally oriented }\end{array}$ \\
\hline Research & $\begin{array}{l}\text { Research priority given to local problems and improvement } \\
\text { of rural life and that of ordinary people }\end{array}$ \\
\hline Provision of intellectual leadership & $\begin{array}{l}\text { Cutting-edge leadership capable of leading government, society } \\
\text { and commerce in devising and implementing meaningful } \\
\text { economic and social development }\end{array}$ \\
\hline Manpower development & $\begin{array}{l}\text { Relevant skilled graduates capable of playing a leading } \\
\text { role in the social revolution and production }\end{array}$ \\
\hline $\begin{array}{l}\text { Promotion of social and economic } \\
\text { modernisation }\end{array}$ & $\begin{array}{l}\text { Breaking the chains of tradition that inhibit the } \\
\text { African genius capable of advancing social and } \\
\text { economic development }\end{array}$ \\
\hline $\begin{array}{l}\text { Promotion of intercontinental unity } \\
\text { and international understanding }\end{array}$ & $\begin{array}{l}\text { Responsibility to emancipate the African continent } \\
\text { from isolation, marginality and pursuit of pan-Africanism }\end{array}$ \\
\hline
\end{tabular}

Source: Yesufu, 'Emerging Issues of the 1970s', 42-43

There was a clear agreement among the members of the AAU that the African university must be a developmental one. However, Wandira raised critical concerns about what he termed the 'Yesufu University Model' which emerged from the 1972 AAU workshop. He argued that this new model was not necessarily free from the internal 'conflicts' inherent in the very general idea of the university. ${ }^{92}$ The actual role of the university in development and its relationship with the state remained open to conflicts. The questions of academic freedom and autonomy versus the role of the state were not clearly defined. Attempts to create an African university in the 1970s coincided with the realities of collapsing African economies. The existing African universities inevitably began to succumb to the debilitating economic crisis. Inevitably, the 1970s became characterised by rising student protests. Colin Legum termed 1971 'the year of the students' as eleven universities had to close down and dissolve their student unions. ${ }^{93}$ This means that the 1972 AAU workshop took place within a context of crisis and was bound to fail, however well meaning its resolutions were to invent relevant universities reflecting African identity and African soul. Despite the difficulties of the time, African intellectuals and academics continued to fight for intellectual spaces, this time outside the declining universities. The formation of the Council for the Development of Social Science Research in Africa (Codesria) in 1973 is a case in point. 


\section{Council for the Development of Social Science Research in Africa}

With the support of donor funding, Codesria emerged as a research council that became a comfortable home for exiled academics like Thandika Mkandawire from Malawi and Archie Mafeje from South Africa. It also became a home for radical leftleaning intellectuals like Samir Amin from Egypt, Mahmood Mamdani from Uganda, Sam Moyo from Zimbabwe, Issa Shivji from Tanzania and many others. In the words of Mamdani, Codesria 'was a ready-made forum for public intellectuals. ${ }^{\text {'94 }}$

What distinguished Codesria was the intense public debates it generated on topical issues affecting Africa, such as African politics and the problem of political authoritarianism; African political economy; dependency; democracy; gender and the emancipation of women; the agrarian question and land reform; neoliberalism and structural adjustment programmes; higher education; economic and social development; and the national question and constitutionalism. What also distinguished Codesria was its 'non-disciplinary' orientation. According to Mamdani:

CODESRIA developed as a non-disciplinary space where all shed our disciplinary specialization and took on non-disciplinary perspective; on the downside, all took on the mantle of political economy. The political economy emerged as the master discipline in the academy, the more it came to be marked by different tendencies; whether on the left or the right, each heralded the human as an 'economic man'...CODESRIA was the home of radical scholars who swore by political economy, as if it were an oath of loyalty. ${ }^{95}$

It would seem from Mamdani's rendition of Codesria's intellectual DNA that it did not directly pursue epistemic decolonisation. It did not engage in any systemic manner with the ontological/identity question that is always linked to the epistemological question. The idea of the university did not preoccupy the Codesria intellectuals in any systemic and consistent way. One may argue that if the decolonisation trajectory in Africa moved from the political question to the economic question to the epistemological question, Codesria became stuck in the economic decolonisation stage. Codesria missed an opportunity when Achille Mbembe joined in the 1990s and tried to shift its orientation from the public debate tradition informed by political economy to that of a scholarly community that took up other important themes, such as the discourse and identity/representation that preoccupied the global scholarly community. To its credit, Codesria has maintained a clear oppositional position to imperialism, colonialism and neocolonialism.

However, distinguished Kenyan historian Bethwell A. Ogot has critiqued those who embraced the Marxist political economy of adhering to Western science and Western theoretical tools in order to understand Africa, charging that, 'This was a

Ibid., 78-79. 
sad episode of intellectual capitulation. ${ }^{96}$ This critique applies to Codesria. Mamdani admits that:

The epistemological dimension of decolonization has focused on the categories with which we make, unmake and remake, and thereby apprehend, the world. It is intimately tied to our notions of what is human, what is particular and what is universal. This debate has not found room in CODESRIA. ${ }^{97}$

Codesria is still a vibrant intellectual space and one can only hope that it seriously takes up the topical issue of the decolonisation of the universities and the epistemological question. At a general level, the decline of African intellectualism in the mid1970s provoked two important but broad questions. The first is why African intellectualism declined in the early 1970s. Why did the early decolonisation/Africanisation initiatives fail? These issues led Mazrui to pose the question: 'Who has killed intellectualism in East Africa?'98 The first killer of intellectualism was the rise of brutal dictatorship, symbolised in East Africa by the coming to power of Idi Amin Dada in Uganda through a military coup in January 1971 . He unleashed a reign of terror that had an immense impact on intellectualism. ${ }^{99}$ The second killer was the advent of the Cold War between Western powers and the Soviet bloc. The Cold War not only polarised Africans into pro-West and pro-East ideological dichotomies, but within states like Kenya that became pro-West, '[b]eing socialist or left-wing as an intellectual became a political hazard.100 In the same manner, in a country like Tanzania, led by respected intellectual Mwalimu Julius Nyerere, who chose the path of socialism, the local excessive enthusiasm for socialism bred ideological intimidation in the name of socialism' and respect for Nyerere that Mazrui critiqued as 'Tanzaphilia.. ${ }^{101}$ What suffered severely in both cases was academic freedom.

To Achille Mbembe, a leading postcolonial theorist, the combination of African nationalism and Marxism produced a powerful but false Afro-Marxist radicalism that subsisted on the narcissism of minor difference and victimhood. ${ }^{102}$ Mbembe attempted to go deeper into the limits of African nationalism and Marxism as ideologies of liberation. To Mbembe, two narratives of African identity, namely nativism and Afro-radicalism, emerged from African nationalist and Marxist thought, and their import has been a false claim 'that their [African] race, traditions, and customs confer to them [Africans] a peculiar self irreducible to that of any other human group. ${ }^{103}$ Mbembe is very critical of a preoccupation with identity and authenticity

\footnotetext{
96 Bethwell A. Ogot, 'Rereading the History and Historiography of Epistemic Domination and Resistance in Africa', African Studies Review, 52(1) (2009), 18.

97 Mamdani, 'Between the Public Intellectual and the Scholar', 79 (emphasis added).

98 Mazrui, ‘Towards Re-Africanizing African Universities', 137.

99 Ibid.

100 Ibid., 138.

101 Ibid. See also Mazrui, 'Tanzaphilia: A Diagnosis', Transition, 27 (1967), 13-23.

102 Achille Mbembe, 'African Modes of Self-Writing', Public Culture, 14(1) (2002), 239-273.

103 Achille Mbembe, 'The Cultural Politics of South Africa's Foreign Policy: Between Black (Inter) Nationalism and Afropolitanism' (Unpublished paper presented at Wits Institute of Economic and Social Research, University of the Witwatersrand, 2006), 8.
} 
as well as of initiatives aimed at breaking away from imperialism, neocolonialism, dependence and neoliberalism. To him, besides these preoccupations being fed by a 'neurosis of victimhood' linked to the triple events of slavery, colonialism and apartheid, they also promote the 'ghettoisation' of Africa. ${ }^{104}$ Cascading from this analysis, Mbembe would not support the African struggle for the decolonisation of universities as this would amount to what he has caricatured as Africans' desire 'to know themselves (identity), to recapture their destiny (sovereignty), and to belong to themselves in the world (autonomy). ${ }^{105}$ To him this is a result of a preoccupation with African history as nothing but a catalogue and a 'series of subjugations, narrativised in a seamless continuity.' ${ }^{106}$

While the warnings about the limits of both Marxism and African nationalism as philosophies of liberation are well taken, there is a danger that Mbembe's analysis might fall into unintended apologia for the slave trade, colonialism and apartheid. Epistemological decolonisation is not about 'navel-gazing', 'nativism' and 'ghettoisation'. It is about cognitive/epistemic justice as an essential prerequisite for social justice. ${ }^{107}$ Epistemological decolonisation is about opening rather than closing the academy to a plurality of knowledges. Mbembe's analysis is also not critical of globalisation and the notions of global knowledge that continue to circulate from the hegemonic centres of Europe and North America. Epistemological decolonisation is important in dealing with the asymmetrical global intellectual division of labour in which Europe and North America not only masquerade as teachers of the rest of the world, but also as sites of theory and concept production, which are then consumed by Africa and the rest of the world. This point is brought home clearly by Raewyn Connell: 'Modern universities and their staff and students exist in a global economy of knowledge, with a definite geography of production and circulation. ${ }^{108}$ Of course, since the outbreak of the RhodesMustFall and the FeesMustFall movements in 2015 and 2016, Mbembe has slightly rethought his earlier position, accepting to some extent the need for decolonisation, and has joined the voices that are critical of the Eurocentric canon and the corporate university. He has also used his knowledge of Frantz Fanon to redefine decolonisation as a necessary rehumanising process, and that of Ngũgĩ wa Thiong'o to underscore the question of the relevance of knowledge. ${ }^{109}$

Taking into account the preceding analysis, it is not surprising that the $1980 \mathrm{~s}$ and 1990s became crisis years for the university in Africa, and attempts to create an African university collapsed. New factors intervened to deepen the crisis. For example, the World Bank introduced a negative attitude towards universities, discrediting them as agencies of development and public institutions worthy of

\footnotetext{
104 Achille Mbembe, 'On the Power of False', Public Culture, 14(3) (2002), 623.

105 Mbembe, 'African Modes of Self-Writing', 242 (emphasis added).

106 Ibid., 243.

107 Boaventura de Sousa Santos, Epistemologies of the South: Justice against Epistemicide (London and Boulder, CO: Paradigm Publishers, 2014).

108 Raewyn Connell, 'Decolonizing Knowledge, Democratizing Curriculum' (Unpublished paper prepared for University of Johannesburg Discussions on Decolonization of Knowledge, March 2016), 1.

109 Mbembe, 'Decolonizing the University: New Directions'.
} 
government and international support. Instead, the World Bank prioritised secondary education. ${ }^{110}$ The idea of creating African universities died as the powerful international forces of neoliberalism and global finance posited that Africa had no need for universities, and that what was taught at them was irrelevant to the needs of the global market and national development. ${ }^{111}$ It was during this period that the humanities and social sciences were challenged to demonstrate their relevance and value to the technically and narrowly defined programme of development that was now driven by the Bretton Woods institutions under the so-called structural adjustment programmes (SAPs). ${ }^{112}$ The example of history departments mutating overnight into departments of development studies and departments of international studies to avoid closure and to demonstrate relevance to the demands of a world captured by market forces, is instructive of the power of neoliberal interventions into higher education.

Falola identifies four major factors that led to the decline of universities in Africa in the 1980s. The first factor was the decline in African economies, which made it impossible for African governments to continue financing higher education. The second was the migration of academics to Europe and North America. The third was the rising tide of political authoritarianism, noted above, and the fourth was the marginalisation of Africa in global affairs and the renewal of dependency through the SAPs. ${ }^{113}$ The consequences of these developments have been far reaching for the university in Africa. According to Falola, the role of academics in society was diminished, leading to a crisis of self-production as it became difficult to attract gifted young people into the academic profession. Those academics that remained behind literally abandoned academic work and concentrated on survival. In addition, scholarship itself suffered debasement as academics pursued wealth, fame and power, to the extent of reducing themselves to being sycophants to those in state power. Lastly, university education underwent instrumentalisation as more and more people wanted it not for knowledge's sake but for certificates, diplomas, degrees and occupational mobility. The focus became 'on how to pass examinations, then throw away the books and seek remunerative occupations.' ${ }^{114}$ The neoliberal project spearheaded by the World Bank and the International Monetary Fund constituted 'one of the most significant changes and challenges to face higher educational systems in Africa since independence. ${ }^{115}$ The forced mutation of the university in Africa into a 'corporate university' in the 1980s and 1990s was a major blow to the struggles for a decolonised university. Markets became the major agents of coloniality.

110 World Bank, Financing Education in Developing Societies: An Exploration of Policy Options (Washington, DC: World Bank, 1986). 111 Adebayo Olukoshi and Paul Tiyambe Zeleza, 'Introduction: The Struggle for African Universities and Knowledges' in Paul Tiyambe Zeleza and Adebayo Olukoshi, eds., African Universities in the Twenty-First Century: Volume 1: Liberalisation and Internationalisation (Dakar: Codesria, 2004), 1-18.

112 Ali A. Mazrui, 'The African University as a Multinational Corporation: Problems of Penetration and Dependency', Harvard Educational Review, 45(2) (1975), 191-210.

113 Falola, Nationalism and African Intellectuals.

114 Ibid., 216-217.

115 Olukoshi and Zeleza, 'Introduction', 6. 


\section{The corporate university in Africa}

The African struggle for an African university failed in the 1960s and 1970s. The late 1980s and the 1990s witnessed the rise of the 'corporate university', characterised not only by the invasion of the university by business models but also by 'great antipathy to thinking. ${ }^{116}$ The corporate university is a product of the triumph of the Washington Consensus, which routinised the neoliberal dispensation.

Besides well-known features of neoliberalism such as deregulation, privatisation and withdrawal of the state from provision of social services, Paul Tiyambe Zeleza has identified what he terms the 'six Cs' that speak directly to how higher education has been shaped by neoliberal thinking. First is the corporatisation of management through adopting business models for organising and administering the university. Second is the process of collectivising access through the massification of higher education, continuing learning and accountability to outside stakeholders. Third is the commercialisation of learning through expansion of private universities, private programmes in public universities and vocational training. Fourth is the commodification of knowledge through increased production, sponsorship and dissemination of research by commercial enterprises, applied research and intellectual property norms. Fifth is the computerisation of education through incorporating new information technologies into the knowledge activities of teaching, research and publication. Sixth is the connectivity of institutions of higher learning through institutional cooperation and coordination within and across countries. ${ }^{117}$

Within the corporate university arose what Lewis R. Gordon terms the 'academic managerial class' using 'corporate analogs' as its basis of governing the institutions. ${ }^{118}$ Gordon elaborates that the rise of this 'academic managerial class has been, perhaps the most catastrophic development in the modern university. ${ }^{119}$ The catastrophic aspect of this phenomenon is multidimensional. Firstly, this academic managerial class, according to Gordon, is 'unlike past scholars who so happened also to administrate' because it 'no longer has knowledge as part of its telos. ${ }^{120}$ Worse still, this academic managerial class 'has folded onto itself as the object of its own preservation, and the result is its proliferation. ${ }^{121}$ Gordon further characterises the composition of this academic managerial class as 'consisting of failed academics and scholars whose credentials do not extend beyond their doctorates' and who practise the 'sociology of revenge and entrenched resentment toward productive and influential scholars.' ${ }^{122}$ It is this academic managerial class that 'seeks inspiration from the corporate world

116 Lewis R. Gordon, Disciplinary Decadence: Living Thought in Trying Times (Boulder, CO, and London: Paradigm Publishers, 2006), 5.

117 Paul Tiyambe Zeleza, Rethinking Africa's Globalization: Volume 1: The Intellectual Challenges (Trenton, NJ: Africa World Press, 2003). See also Paul Tiyambe Zeleza, 'Neo-Liberalism and Academic Freedom' in Paul Tiyambe Zeleza and Adebayo Olukoshi, eds., African Universities in the Twenty-First Century: Volume 1: Liberalisation and Internationalisation (Dakar: Codesria, 2004), $42-68$.

118 Gordon, Disciplinary Decadence, 9-10.

119 Ibid., 10.

120 Ibid.

121 Ibid.

122 Ibid. 
primarily because of a form of decadence of the imagination in which corporate management is equated with management itself. ${ }^{123}$

It is within this context of a decadent corporate university presided over by an equally decadent academic managerial class that many scholars found themselves in the midst of what Mamdani termed the 'market place.'. ${ }^{124}$ Within this 'market place', evaluation of scholarship is through the principles of quantification and annual reports. It is also within this context that research is measured in accordance with 'the immediate demands of a consumer society'; anything which looks into the long term is discredited as irrelevant. ${ }^{125}$ Thus, instead of deploying a pedagogy that really develops informed African citizenry, education is reduced to the skilling of students. What has compounded the crisis in a corporate university is what Gordon terms 'disciplinary decadence':

Disciplinary decadence is the ontologizing or reification of a discipline. In such an attitude, we treat our discipline as though it was never born and has always existed and will never change or, in some cases, die. More than immortal, it is eternal. Yet as something that came into being, it lives, in such an attitude, as monstrosity, as an instance of a human creation that can never die. ${ }^{126}$

For the decolonisation of knowledge to take place, it is important for this 'disciplinary decadence' to die. This death must take the form of a discipline suspending 'its own centering because of a commitment to questions greater than the discipline itself'.127 But what has really plunged the corporate university into violent crisis is its commodification of education, which has reduced students to customers and the professoriate to an academic proletariat. Within the corporate university, higher education has been turned into a seductive 'marketable product, rated, bought and sold by standard units, measured, counted and reduced to staple equivalence by impersonal, mechanical tests and therefore readily subject to statistical consistency, with numerical standards and units. ${ }^{128}$ The pegging of higher education at a commercial value has not only closed out of the university students from poor family backgrounds, it has also burdened those who went through the corporate university with a huge debt. This reality has provoked student protests across the world. A good example of the most recent student protest is the RhodesMustFall (RMF) movement that broke out in 2015 in South Africa and that inspired protests in other parts of the world. The RMF movement is analysed below as a typical example of the resurgent call for decolonisation of the university in the twenty-first century, at a time when the

123 Ibid., 10-11.

124 Mahmood Mamdani, Scholars in the Market Place: The Dilemmas of Neo-Liberal Reform at Makerere University, 1989-2005 (Dakar: Codesria, 2007).

125 Gordon, Disciplinary Decadence, 11

126 Ibid., 4-5 (emphasis in original).

127 Ibid., 34.

128 Achille J. Mbembe, 'Decolonizing the University: New Directions', Arts and Humanities in Higher Education, 15(1) (2016), 30. 
wider social role of the institution is, in the words of Bill Readings, 'now up for grabs' and '[i]t is no longer clear what the place of the University is within society nor what exactly [the] nature of that society is. ${ }^{129}$

\section{RhodesMustFall and resurgent struggles for a decolonised university}

By 2015 the idea of the university prescribed by the colonial and apartheid past was targeted by radical student movements in South Africa. While on the surface the 2015/2016 RMF movement was sparked by the existence of the offensive statue of leading British imperialist Cecil John Rhodes at the University of Cape Town, there were deeper challenges behind this movement. ${ }^{130}$ These included the deepening and widening socioeconomic inequalities that breed poverty; the legitimate demand for expansion of access to higher education, which speaks directly to social justice issues connected to the skewed demographic and unequal economic wealth distribution; low throughput and retention of students; the irrelevance of what is taught in universities and its misalignment with labour market demands; and the connection between student demands and workers' demands, which manifested in the call for the outsourcing of workers to end. A combination of these factors forced the students to begin the struggle of 'nibbling at resilient colonialism in South Africa. ${ }^{131}$

The South African students who spearhead the RMF and the FeesMustFall (FMF) movements must be understood broadly as heirs to the long-standing struggles for an African university and the wider decolonisation of Africa. What the South African students put to the fore is Oginga Odinga's 'Not Yet Uhuru' clarion call to continue the struggle for decolonisation even after the dismantlement of direct colonial administrations and juridical apartheid. ${ }^{132}$ It is not surprising that South Africa, hailed by neoliberals as a democratic society with one of the most liberal, progressive constitutions in the world, has become the site of resurgent decolonial struggles, because what was gained in 1994 was democracy without decolonisation. The celebrated constitution 'constitutionalised injustices. ${ }^{133}$ 'Neo-apartheid' rather than 'post-apartheid' best describes present-day South Africa, where racism, inequalities and exclusions signify a problematic democracy; where a dispossessed black majority refuses to accept the constitutionalised apartheid theft of resources and their continued concentration in the hands of the minority white population; and where a few black people use control of the state to engage in bureaucratic petit-bourgeois looting.

129 Bill Readings, The University in Ruins (Cambridge, MA: Harvard University Press, 1996), 2.

130 Sabelo J. Ndlovu-Gatsheni, 'Why Are South African Universities Sites of Struggle Today?' The Thinker: A Pan-African Quarterly for Thought Leaders, 4(70) (2016), 52-61.

131 Francis B. Nyamnjoh, Rhodes Must Fall: Nibbling at Resilient Colonialism in South Africa (Bamenda: Langaa Research and Publishing Common Initiative Group, 2016).

132 Ajuma Oginga Odinga, Not yet Uhuru (London: Heinemann, 1968). See also Sabelo J. Ndlovu-Gatsheni, 'Sites of Struggle: South African Universities and Student Protests' (Public Lecture delivered at the Conference on Middle Classes, Protests and Social Change in Africa and Beyond, University of Stellenbosch, 17-21 March 2017).

133 Mogobe B. Ramose, 'I Conquer, Therefore I Am the Sovereign: Reflections upon Sovereignty, Constitutionalism, and Democracy in Zimbabwe and South Africa' in P.H. Coetzee and A.P.J. Roux, eds., The African Philosophy Reader (second edition) (London: Routledge, 2003), 470. 
While Susan Booysen's definition and analysis of the South African student movement is limited by her neoliberal concerns with the governance failures of the African National Congress (ANC) as a former liberation movement, she is correct in locating the student struggles within the broader revolts against the sociopolitical dispensation resulting from the 1994 social compact between big business, the white ruling elite and the black-dominated liberation movements. ${ }^{134}$ What the RMF and FMF movements have successfully brought to the fore are the long-standing but unresolved issues of opening the doors of learning and education to everyone, as promised by the ANC in the Freedom Charter of 1955; rescuing the university from capture by neoliberal market forces and repositioning it as a public good; rethinking and redefining the university as a truly African public institution serving African communities; rethinking and rearticulating the broader philosophical foundations of higher education in Africa to enhance relevance; financing and funding higher education to enable access; decolonising the epistemology, curricula and alienating institutional cultures of the universities; democratising student-staff relations to enhance teaching and learning; using indigenous languages for learning and teaching; ending the dehumanising outsourcing of black workers; as well as the depatriarchalisation, deracialisation and dewesternisation of universities. ${ }^{135}$

However, like all struggles of decolonisation, the RMF and FMF movements were inevitably riddled with internal ructions, contradictions, ambiguities and struggles-within-the-struggle. Jonathan Jansen's As By Fire captures some of the key undersides of the student movements, ${ }^{136}$ including crises of leadership and the use of violence, which risked affecting the legitimacy of RMF and FMF. Universities became sites of violence as the vice-chancellors called in private security companies, resulting in the militarisation of campuses. Rather than diminishing it, this contributed to an escalation in the violence. Other issues were the movements' patriarchal tendencies; intolerance of divergent views; the sometimes careless use of the discourse of racism, which affected the initial multiracial quality of the student movements; weak responses to the realities of the intersectionality of student struggles, which caused struggles within the struggle as the lesbian, gay, bisexual and transgender community complained of being sidelined; and the challenge of avoiding being used by external political forces, another issue that nearly undermined the noble cause of the students' struggle. However, the fact remains that South African students have taken the torch of epistemic decolonisation and successfully put decolonisation squarely on the public agenda. In the process, they have forced universities to revive their mission to be torch-bearers of equality, democracy, justice and human rights. Whether they will genuinely rise adequately to these noble demands is yet to be seen.

134 Susan Booysen, 'Two Weeks in October: Changing Governance in South Africa' in Susan Booysen, ed., Fees Must Fall: Student Revolt, Decolonization and Governance in South Africa (Johannesburg: Wits University Press, 2016), 22-52.

135 Ndlovu-Gatsheni, 'Sites of Struggle: South African Universities and Student Protests'. See also Assié-Lumumba, Higher Education in Africa, where she demonstrates that Codesria has identified these same problems and challenges that are poised to haunt the university in Africa.

136 Jonathan Jansen, As By Fire: The End of the South African University (Cape Town: Tafelberg, 2017). 


\section{Conclusion: What is to be done?}

This article has provided a comprehensive historiographical analysis of the contested idea of the university and the concomitant struggles it has provoked across time. It has also highlighted the paradoxes and limits of the long struggles for an African university, and shown that decolonisation has a long genealogy in Africa, even though it has re-emerged in its current radical form from Latin America, where it has been named decoloniality. One cannot ignore the paradoxical structural situation bequeathed on Africa by colonialism, in which 'the same education which had produced nationalists eager to end colonial rule and to establish African selfgovernment has also perpetrated cultural colonialism. ${ }^{137}$ Globalisation has further complicated the decolonisation struggle because we have to constantly take cognisance of the fact that the envisaged decolonised African university has to reconcile

the legitimate but particularistic concerns of society with the desirable but universalistic perspectives of the genius of the world university community. The identity of the African university in development will depend on the balance it can, from time to time, strike between the particularistic and universalistic tendencies of its continent. ${ }^{138}$

Finally, the article reiterates some concrete steps that have to be taken, especially by academics and intellectuals, in continuing the struggle for epistemological decolonisation. At first they have to secure Africa as a legitimate epistemic base from which to look at the world. As Ngũgĩ wa Thiong'o warned, African academics 'cannot afford to be intellectual outsiders in our own land. We must reconnect with the buried alluvium of African memory - that must become the base for planting African memory anew in the continent and the world'. ${ }^{139}$ Secondly, African academics have to consistently shift the geography and biography of knowledge because what masquerades as 'global knowledge' has a hegemonic centre which is Europe and North America - that centre has to be moved so as to privilege Africa-centred knowledge. Thirdly, African academics have to invest in 'rethinking thinking itself' as part of launching epistemic disobedience to Eurocentric thinking. They have to fully embrace the idea that all human beings are born into valid, legitimate and functional knowledge systems as part of launching epistemic disobedience. Finally, African academics must be true to themselves and accept that they are products of very problematic 'westernised' universities and consistently open themselves up to the painstaking but decolonial process of 'learning to unlearn' in order to relearn. ${ }^{140}$ These four processes must underpin the current initiative of 'doing decolonial change'.

137 Mazrui, 'The African University as a Multinational Corporation', 194.

138 Wandira, The African University in Development, 132 (emphasis in original).

139 Ngũgĩ wa Thiong'o, Secure the Base, 54.

140 Madina V. Tlostanova and Walter D. Mignolo, Learning to Unlearn: Decolonial Reflections from Eurasia and the Americas (Columbus, OH: Ohio University Press, 2012). 